of Simulium and Aedes, vectors of onchocerciasis and dengue, respectively, while, $B s$ is very effective for controlling Culex species, vectors of filariasis and encephalitis. Data from the operational use of microbial larvicides in several countries, in the past two decades, have confirmed the effectiveness of $B t i$ and $B s$ and their safety to non-target species. On the other hand, Culex populations intensively sprayed with $B s$, can display resistance. Data shows that $B s$ should be used into integrated programs with other control agents such as Bti, in order to avoid these phenomena. Resistance is unlikely to appear towards Bti due to its multiple toxins. - (May 24, 2002 ).

*E-mail: mhneves@cpqam.fiocruz.br

\section{X-RAY DIFFRACTOMETRY APPLIED TO THE COM- PARATIVE STUDY OF PROCESSES OF FORMATION OF AUTOMOTIVE BATTERIES}

\section{Lucila E. P. Borges}

Departamento de Engenharia de Minas, CTG-UFPE, Recife, PE, Brazil.

Presented by Valderez P. Ferreira

$\mathrm{X}$ ray diffraction was applied to the investigation of the main steps in lead acid battery production (mixing, soaking and formation) in order to improve manufacturing conditions and to contribute with a theoretical understanding of these processes.

In the first step, mixing, the following results were obtained: (a) liquid nitrogen freezing of the paste was effective; (b) the reaction was instantaneous; (c) it is directly related to the amount of acid added.

In the soaking step, plates with a high content of total sulfate display a final monobasic lead sulfate content bigger than those displayed by plates with low content of total sulfate. In order to explain this behavior, two hypotheses are proposed: (a) 3BS could lead to monobasic sulfate crystallization; and (b) 1BS initially present in the plates could act as seeds for further crystallization. Crystal sizes were also followed as a function of time during the soaking period, demonstrating the possibility of extending the use of X-ray diffraction in the observation of crystal sizes in this and any other step of battery production.

In continuous current formation it was observed that higher temperatures $\left(60^{\circ} \mathrm{C}\right)$ are favorable, affected by an increase in current and especially by the interaction: increase in current vs. increase in density. The best results of plate formation were obtained with plates rich in triba- sic lead sulfate. It was found that the total charge used in the industry is too high and a reduction of up to $43 \%$ of the charge yields excellent results, with $\mathrm{PbO}_{2}$ contents as high as $92 \%$ with an average of $80 \%$.

A laboratory test of pulsed formation showed that longer time is the main factor in order to achieve better results, moreover longer pulses in experiments with short times also yield higher contents of $\mathrm{PbO}_{2}$.

In a comparison of both formation schemes it was observed that pulsed formation was more efficient, with respect to total $\mathrm{PbO}_{2}$ obtained, with plates richer in tetrabasic sulfate. In continuous formation, under the same experimental conditions, no tetrabasic sulfate remains unformed. - (May 24, 2002 ).

\section{OXYGEN ISOTOPES INTERNAL EQUILIBRIUM IN MAGMATIC EPIDOTE-BEARING GRANITOIDS}

VAlderez P. Ferreira ${ }^{1}$, John W. VAlley ${ }^{2}$, Alcides N. Sial ${ }^{1}$ and Michael J. Spicuzza ${ }^{2}$

${ }^{1}$ NEG-LABISE, Department of Geology, UFPE, Cx. Postal 7852, 50732-970 Recife, PE, Brazil.

${ }^{2}$ Department of Geology and Geophysics, University of Wisconsin, 1215 W. Dayton St., Madison, WI, 53706, USA.

In this study we present oxygen isotope compositions of mineral separates from three metaluminous epidote-bearing granitoid series from northeastern Brazil.

Zircon has an overall $\delta^{18} \mathrm{O}$ variation of $\sim 5 \%$, ranging from $5.72 \%$ to $10.30 \%$, but is very homogenous within a single pluton. The highest values of $\delta^{18} \mathrm{O}$ (zircon) $(9.88 \% \circ \pm 0.35 \%$ n $=13$ samples) are for the calc alkalic granitoids, which are slightly, but significantly higher than those for high-K calc-alkalic granitoids $(9.10 \% \circ 0.41 \% \circ \mathrm{n}=19$ samples $)$ with little overlap. Values for these granitoids greatly differ from the average for the shoshonitic granitoids $(7.43 \% \circ \pm 0.19 \%$; $\mathrm{n}=5$ samples), and from that for the São Rafael pluton, a high-K calc-alkalic granitoid $(5.92 \% 00.26 \% \circ \mathrm{n}=9$ samples). These differences repeat for the other analyzed minerals, with little overlap of values. There is a good positive correlation between mineral pairs in the three series, although quartz-epidote and zircon-epidote fractionations are higher than predicted for equilibrium at magmatic temperatures. Measured mineral-mineral fractionations suggest continuous sub-solidus inter-mineral isotope exchange among all minerals except zircon. Calculated $\delta^{18} \mathrm{O}$ (magma) values using whole rock $\mathrm{SiO}_{2}$ contents and $\delta^{18} \mathrm{O}$ (zircon) values are up to $1 \%$ lower that those 